\title{
DUAL ECTOPIC THYROID: LINGUAL WITH INFRAHYOID THYROID ECTOPIA: AN OCCASIONAL OCCURRENCE
}

Tharali Chandrasekar Narendran', Alankrith Ramesh Kashyap², Raveendran Rani Arun Prasanth ${ }^{3}$, Mohamed Musthafa ${ }^{4}$, Yella Suryakiran 5

${ }^{1}$ Assistant Professor, Department of General Surgery, SRM Medical College Hospital and Research Centre, Chennai. ${ }^{2}$ Post Graduate, Department of General Surgery, SRM Medical College Hospital and Research Centre, Chennai. ${ }^{3}$ Post Graduate, Department of General Surgery, SRM Medical College Hospital and Research Centre, Chennai. ${ }^{4}$ Professor, Department of General Surgery, SRM Medical College Hospital and Research Centre, Chennai.

${ }^{5}$ Post Graduate, Department of General Surgery, SRM Medical College Hospital and Research Centre, Chennai.

\section{ABSTRACT}

Ectopic thyroid gland is a well-spoken developmental anomaly. We here present a young female with a unique anatomical variant of this anomaly namely dual ectopic thyroid. The purpose of this report is to emphasize the importance of thorough evaluation of ectopic thyroid tissue and performing a thyroid scan in every case of ectopic thyroid to accurately identify all sites of functioning thyroid tissue and commence appropriate treatment.

\section{KEYWORDS}

Dual Ectopic Thyroid, Developmental Anomaly, Thyroid Scan, Hypothyroidism.

HOW TO CITE THIS ARTICLE: Narendran TC, Kashyap AR, Prasanth RRA, et al. Dual ectopic thyroid: lingual with infrahyoid thyroid ectopia: an occasional occurrence. J. Evolution Med. Dent. Sci. 2016;5(43):2718-2719, DOI: 10.14260/jemds/2016/635

\section{INTRODUCTION}

Dual ectopic thyroid is very rare with only 32 cases reported in literature with $70 \%$ of the time absent thyroid gland in its normal position with a prevalence of $1: 100000 .[1,2] 90 \%$ of these are lingual thyroid and others may be sublingual (Suprahyoid, infrahyoid at the level of hyoid bone), prelaryngeal, mediastinal; though other unusual sites have also been accounted for: trachea, submandibular, lateral cervical regions, axilla, palatine tonsils, carotid bifurcation, iris of eye, pituitary gland, heart, thymus, oesophagus, duodenum, gallbladder, stomach. ${ }^{[1,3]}$ This makes a dual ectopic thyroid an important entity from both surgical and endocrinological point of view and has to be evaluated very carefully.

\section{CASE REPORT}

A young female has been known to have a small midline cervical mass from the age of 8 years. The presumptive diagnosis was thyroglossal duct cyst. FNAC done and reported as normal thyroid tissue, hence left untreated. Now at the age of 18 years, patient presented with complaints of difficulty in swallowing and with hypothyroidism features - constipation, weight gain, polymenorrhoea and menorrhagia. A swelling was palpable in the anterior aspect of the neck below hyoid bone. On oral examination, a swelling was noticed at the posterior aspect of the tongue near the foramen caecum. Hence advised for thyroid function test, USG neck and thyroid scan [Figure 1, 2]. Endoscopy was done for direct visualization of lingual thyroid gland [Figure 3].

Financial or Other, Competing Interest: None.

Submission 12-04-2016, Peer Review 07-05-2016,

Acceptance 13-05-2016, Published 30-05-2016.

Corresponding Author:

Dr. Alankrith Ramesh Kashyap,

Room 303, PG Medical Gents Hostel,

SRM College Hospital \& Research Centre,

SRM Nagar, Kattankulathur,

Chennai-603203.

E-mail: koolchant@gmail.com

DOI: 10.14260/jemds/2016/635

\begin{tabular}{|c|c|c|c|}
\hline $\begin{array}{c}\text { Thyroid Function } \\
\text { Test }\end{array}$ & Before Treatment & $\begin{array}{c}\text { After Treatment } \\
\text { (with L-thyroxine } \\
\mathbf{3 0 0} \boldsymbol{\mu g} \text { ) }\end{array}$ & Normal Range \\
\hline Free T3 & $0.65 \mathrm{pg} / \mathrm{ml}$ & $2.72 \mathrm{pg} / \mathrm{ml}$ & $(1.4$ to $4.2 \mathrm{pg} / \mathrm{ml})$ \\
\hline Free T4 & $0.42 \mathrm{ng} / \mathrm{dl}$ & $1.45 \mathrm{ng} / \mathrm{dl}$ & $(0.8$ to $2.0 \mathrm{ng} / \mathrm{dl})$ \\
\hline TSH & $10.46 \mu \mathrm{IU} / \mathrm{ml}$ & $2.49 \mu \mathrm{IU} / \mathrm{ml}$ & $(0.3$ to $6.16 \mu \mathrm{IU} / \mathrm{ml})$ \\
\hline
\end{tabular}

Fig. 1: Thyroid Function Tests

\section{Ultrasonogram Neck}

- Absent thyroid lobes in thyroid fossa.

- Ectopic thyroid gland in midline-anterior portion of neck.

Thyroid Scan

(Tc 99m pertechnetate isotope scan) [Figure 2].

The study shows evidence of functioning thyroid tissue in the midline anterior portion of neck above the thyroid cartilage? Ectopic thyroid.

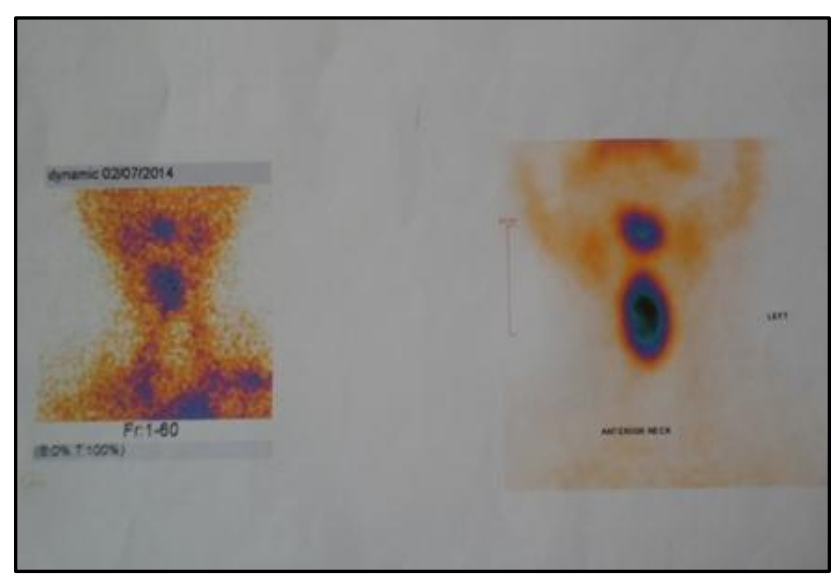

Fig. 2: Radio-Isotope Thyroid Scan showing Both Thyroid Ectopia (Lingual and Infrahyoid) with Absence of Thyroid Gland in Normal Position 


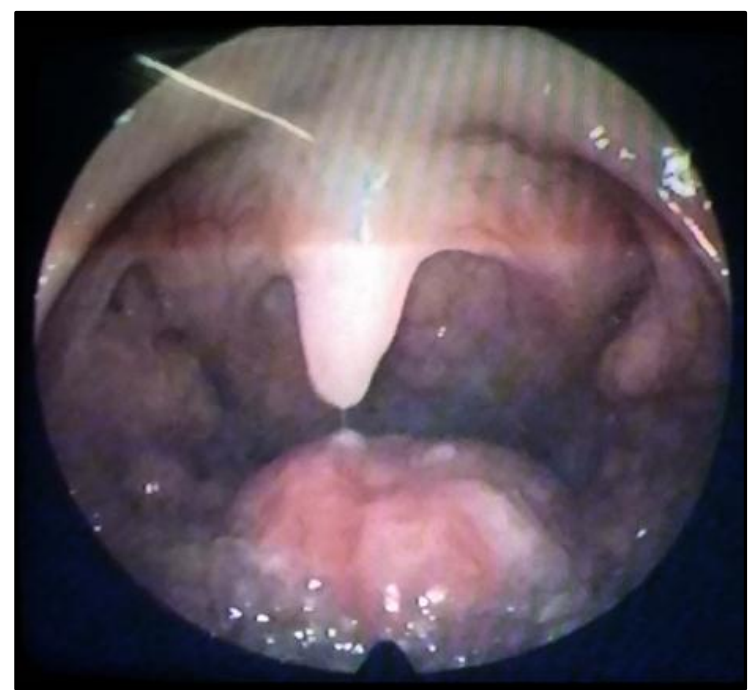

Fig. 3: Endoscopic View of Lingual (Ectopic) Thyroid

The patient was started on L-thyroxine following which the swelling is gradually reduced in size.

\section{DISCUSSION}

Ectopic thyroid incidence reported is $4000-7000$ and $90 \%$ of the time it being the only functioning thyroid tissue which occurs due to any arrest or irregularity in its decent from foramen caecum to its normal position (Front of trachea).[2,4,5] Pathogenesis for occurrence of thyroid ectopia have been postulated and studied on physiological and biomolecular basis- maternal anti-thyroid antibodies arresting the decent of the gland and the role of transcription factors viz. - TITF-1, TITF-2, PAX-8, HHEX.[2,3,4] TITF-1 has a major activity in thyroid gland organogenesis and expression of genes specific for thyroid follicular cells in adult life; TITF-2 (FOXE1) is obligatory for thyroid migration process (Mutation results in sublingual thyroid ectopia); PAX-8 is vital for thyroid cell precursors survival and their functional differentiation; HHEX mediates and sustains expression of TITF-1, TITF-2 and PAX-8.[3,4]

Clinical spectrum of ectopic thyroid can range more often from asymptomatic initially to hypothyroidism (In stressful conditions like puberty, pregnancy, infections, trauma) to rarely hyperthyroidism, benign or malignant transformation. [3] Symptoms arise due to the enlargement in size of the gland - cough, dyspnoea, stridor, sleep apnoea or they can present with features of hypothyroidism, especially in adolescents.[1,3]

Ultrasound neck is an important, easily available and nonintrusive diagnostic modality, which can be initially used to evaluate neck masses coupes with Thyroid Function Tests (TFT), which can assess the physiological activity of the thyroid gland.[3]
Thyroid scintigraphy with Tc99 pertechnetate plays a decisive role in recognizing all ectopic thyroid sites, evaluating their size, distribution, functional status and also delivers a lesser radiation brunt and better safety profile compared to I131 (Radioactive Iodine-131) and confirm the presence or absence of eutopic thyroid.[1,3,5]

Once the diagnosis of an ectopic thyroid gland has been established and if patient is in hypothyroid state then exogenous thyroxine supplementation therapy has to be started to acquire the euthyroid status and also shrink the gland size.[1,3] Malignancy if at all suspected in ectopic thyroid can be readily diagnosed by FNAC, which has a specificity of $95 \%$ and surgery is indicated with other indications for surgery being obstructive symptoms, bleeding, cystic degeneration and ulceration. ${ }^{[1,3]}$

\section{CONCLUSION}

The simultaneous appearance of double thyroid ectopia with no thyroid gland in the normal site (Eutopic) in the neck is a rare embryological aberration. Apart from the description of only thirty-two cases of double ectopic thyroid, no case of an ectopic lingual thyroid combined with infrahyoid region ectopic gland has been reported in literature. Continuous therapy with L-thyroxine should reduce the size of the goitre as a result of TSH suppression and may also prevent pituitary enlargement secondary to the hypothyroidism associated with an ectopic thyroid. Surgical or radioactive iodine treatments are seldom necessary, but may be needed when marked hypertrophy of the ectopic gland produces pressure symptoms not responding to suppressive therapy or in rare cases of malignant lesions in the ectopic gland.

\section{REFERENCES}

1. Soni Kaushalendra, Mishra Divyangi, Sakhi Pramod, et al. Dual ectopic thyroid: a rare entity, case report with review of literature. Sch J Med Case Rep 2014;2(2):114-7.

2. Raza SA, Saldanha M, Nagalotimath US, et al. Dual ectopic thyroid. National Journal of Otorhinolaryngology and Head \& Neck Surgery 2013;1(10):26-7.

3. Ibrahim Nasiru Akammu, Fadeyibi Idowu Olusegun. Ectopic thyroid: aetiology, pathology and management. Hormones 2011;10(4):261-9.

4. Noussios George, Anagnostis Panagiotis, Goulis Dimitrios G, et al. Ectopic thyroid tissue: anatomical, clinical and surgical implications of a rare entity. European Journal of Endocrinology 2011;165:375-82.

5. Meng Z, Lou S, Tan J, et al. Scintigraphic detection of dual ectopic thyroid tissue: experience of a chinese tertiary hospital. PLoS ONE 2014;9(4):e95686. doi:10.1371/journal.pone.0095686. 